\title{
TìNH TRẠNG DI CĂN HẠCH CỦA UNG THƯ TUYÉN GIÁP THỂ BIẸT HÓA Ở NAM GIỚI
}

\author{
Nguyễn Xuân Hậu ${ }^{1,2, 凶}$, Nguyễn Thanh Long ${ }^{1}$, \\ Nguyễn Xuân Hiền² và Lê Văn Quảng ${ }^{1,2}$
}

${ }^{1}$ Trường Đại học Y Hà Nội

${ }^{2}$ Bệnh viện Đại học Y Hà Nội

Nghiên cứu được tiến hành nhằm đánh giá tình trạng di căn hạch trong ung thư tuyến giáp thể biệt hóa ở nam giới tại bệnh viện Đại học Y Hà Nội. Nghiên cứu tiến cứu trên 102 bệnh nhân nam giới ung thư tuyến giáp thể biệt hóa được phẫu thuật tại Bệnh viện Đại học Y Hà Nội từ tháng 7/2018 đến tháng 08/2020. Độ tuổi trung bình là 40,9 9 13,0 tuổi. Khối u chủ yếu ở 1 thùy $(79,4 \%)$, kích thước $\leq 1 \mathrm{~cm}(65,7 \%)$. Đánh giá trên siêu âm chủ yếu là TIRADS 4 (66,6\%), tỉ lệ chọc hút tế bào kim nhỏ chẩn đoán ác tính $74,5 \%$. Đa số các bệnh nhân được phẫu thuật cắt toàn bộ tuyến giáp (67,6\%). Tỉ lệ di căn hạch chung là 59,8\%, tỉ lệ di căn hạch cổ nhóm 6 đơn thuần và kèm theo hạch cổ bên lần lượt là $56,1 \%$ và $33,3 \%$. Tỉ lệ di căn hạch tiềm ẩn là $47,1 \%$. Các yếu tố: kích thước $u>1 \mathrm{~cm}$, ung thư hai thùy, u phá vỡ vỏ xâm lấn ra ngoài tuyến liên quan có ý nghĩa thống kê với tình trạng di căn hạch $(p<0,05)$.

Từ khóa: ung thư tuyến giáp thể biệt hóa, nam giới, di căn hạch.

\section{I. ĐẠT VẤN ĐÈ}

Theo GLOBOCAN 2018, ung thư tuyến giáp đứng hàng thứ 5 trong số các loại ung thư ở nữ giới với tỷ lệ mắc chuẩn theo tuổi là 10,2/100.000 dân, đứng hàng thứ 9 chung cho cả 2 giới với 567.233 ca mới mắc và 41.071 ca tử vong hàng năm. ${ }^{1}$ Việt Nam cũng là một trong các nước có tỷ lệ mắc UTTG cao, theo ghi nhận năm 2000, tỉ lệ mắc ung thư tuyến giáp ở nữ xếp thứ 12, ở nam xếp hàng thứ 13 trong các loại ung thư nói chung. ${ }^{2}$ Năm 2018, Việt Nam nằm trong nhóm các nước có tỉ lệ mắc ung thư tuyến giáp cao, đứng hàng thứ 16 với 5418 ca mới mắc, 528 ca tử vong hàng năm. ${ }^{1}$

Các số liệu cho thấy tỉ lệ mắc ung thư tuyến giáp ở nam giới thấp hơn khoảng 2 đến 3 lần so với nữ giới. ${ }^{1}$ Sự khác biệt về tỉ lệ mắc giữa hai

Tác giả liên hệ: Nguyễn Xuân Hậu

Trường Đại học Y Hà Nội

Email: drnguyenxuanhau@gmail.com

Ngày nhận: 03/11/2020

Ngày được chấp nhận: 10/12/2020 giới gợi ý có thể có sự khác nhau về mặt sinh học trong sự hình thành và tiến triển của ung thư tuyến giáp. Một số nghiên cứu chỉ ra rằng hormone giới tính (testosterone và estradiol) có thể gây ảnh hưởng đến sự tổng hợp DNA và phát triển tế bào tuyến giáp, độc lập với tác dụng của TSH, và có những vai trò khác nhau trong sinh bệnh học của UTTG ${ }^{3}$ (E2. Ngoài ra, trên lâm sàng, UTTG thể biệt hóa ở nam giới thường có kích thước u lớn hơn, tỉ lệ di căn hạch và tái phát tại chỗ cao hơn. ${ }^{4}$ Về thời gian sống thêm toàn bộ (OS), một số nghiên cứu trên thế giới cho thấy tiên lượng UTTG ở nam giới xấu hơn nữ giới. ${ }^{5}$ Như vậy, các đặc điểm lâm sàng, cận lâm sàng và đặc biệt là tiên lượng trong ung thư tuyến giáp có sự khác biệt giữa hai giới. Hiện tại ở Việt Nam chưa có nhiều kết quả nghiên cứu về nhóm bệnh nhân nam. Do vậy, chúng tôi thực hiện nghiên cứu này với mục tiêu: Đánh giá tình trạng di căn hạch và các yếu tố liên quan trong ung thư tuyến giáp thể biệt hoá ở nam giới. 


\section{II. ĐỐI TƯỢNG VÀ PHƯƠNG PHÁP}

\section{1. Đối tượng}

Nghiên cứu được thực hiện trên 102 bệnh nhân nam giới được chẩn đoán ung thư tuyến giáp thể biệt hóa và phẫu thuật tại Bệnh viện Đại học Y Hà Nội từ tháng 7/2018 đến tháng 8/2020.

\section{Tiêu chuẩn lựa chọn bệnh nhân}

- Bệnh nhân được chẩn đoán ung thư tuyến giáp và phẫu thuật tuyến giáp tại Bệnh viện Đại học $Y$ Hà Nội, có kết quả xét nghiệm giải phẫu bệnh u tuyến giáp khẳng định là ung thư biểu mô tuyến giáp thể biệt hóa.

- Hồ sơ bệnh án đầy đủ kết quả: khám lâm sàng, cận lâm sàng trước và sau mổ.

- Thời gian từ tháng 07/2018 đến tháng 08/2020.

\section{Tiêu chuẩn loại trù̀}

- Bệnh nhân đã được phẫu thuật ung thư tuyến giáp tại tuyến trước.

- Bệnh nhân cũ đến điều trị tiếp vì tái phát, di căn hoặc lý do khác.

\section{Phương pháp}

Nghiên cứu mô tả tiến cứu.

Các chỉ số nghiên cứu

- Khai thác các thông tin lâm sàng, cận lâm sàng (siêu âm tuyến giáp đánh giá kích thước u, số lượng u, phân loại TIRADS, tình trạng di căn hạch cổ và chọc hút tế bào trước mổ).

- Hạch không phát hiện di căn trước mổ được xác định qua khám lâm sàng và siêu âm vùng cổ.

- Phân loại TIRADS được sự dụng theo TIRADS Jin Young Kwak (2011), phân loại giai đoạn bệnh theo AJCC 2017.
- Phương pháp phẫu thuật:

+ Cắt tuyến giáp toàn bộ khi phát hiện hạch di căn, u kích thước > $1 \mathrm{~cm}$, hoặc xâm lấn cơ trước giáp.

+ Cắt thuỳ và eo tuyến giáp khi khối $u \leq 1 \mathrm{~cm}$, chưa xâm lấn phá vỡ vỏ bao giáp.

+ Vét hạch cổ điều trị khi có tình trạng di căn hạch qua khám lâm sàng, siêu âm, hoặc đánh giá trong mổ.

+ Vét hạch cổ trung tâm dự phòng khi không phát hiện hạch di căn trước mổ.

- Kết quả giải phẫu bệnh sau mổ, khám theo dõi định kỳ sau mổ.

\section{Xử lí số liệu}

Theo phần mềm SPSS 26.0. Thống kê mô tả gồm tỉ lệ phần trăm, trị số trung bình, độ lệch chuẩn trung vị và khoảng tứ phân vị. So sánh sự khác biệt giữa 2 tỉ lệ bằng test $x 2$, Fisher' Exact test, tính nguy cơ tương đối bằng hồi quy Logistic. Mức ý nghĩa thống kê $p<0,05$.

\section{4. Đạo đức nghiên cứu}

- Nghiên cứu được sự đồng ý của Phòng kế hoạch tổng hợp - Bệnh viện Đại học Y Hà Nội.

- Nghiên cứu chỉ nhằm mục đích nâng cao chất lượng chẩn đoán và điều trị bệnh, không phục vụ mục đích nào khác.

- Mọi thông tin thu thập từ bệnh nhân được đảm bảo bí mật và chỉ dùng cho mục đích nghiên cứu.

- Bệnh nhân được điều trị theo phác đồ và nghiên cứu không ảnh hưởng tới kết quả điều trị của người bệnh.

\section{KẾT QUẢ}

\section{Các yếu tố lâm sàng - bệnh học}

Độ tuổi trung bình của các bệnh nhân trong nghiên cứu là 40,9 \pm 13,0, trong đó bệnh nhân nhỏ tuổi nhất là 11 tuổi, cao tuổi nhất là 68 tuổi. Lứa tuổi hay gặp nhất là 15 - 55 tuổi, chiếm tỉ lệ 81,4\%. 
Bảng 1. Đặc điểm khối u giáp qua siêu âm trước mổ

\begin{tabular}{|c|c|c|c|}
\hline \multicolumn{2}{|c|}{ Chỉ số } & $\begin{array}{c}\text { Số bệnh nhân } \\
(\mathrm{N}=102)\end{array}$ & $\begin{array}{l}\text { Tỉ lệ } \\
\text { (\%) }\end{array}$ \\
\hline \multirow{3}{*}{ Kích thước u } & $\leq 1 \mathrm{~cm}$ & 67 & 65,7 \\
\hline & $1 \mathrm{~cm}<\mathrm{u} \leq 2 \mathrm{~cm}$ & 22 & 21,6 \\
\hline & $>2 \mathrm{~cm}$ & 13 & 12,7 \\
\hline \multirow{2}{*}{ Số lượng u } & Đơn ổ & 77 & 75,5 \\
\hline & Đa ổ & 25 & 24,5 \\
\hline \multirow{3}{*}{ Vị trí u } & Một thùy & 81 & 79,4 \\
\hline & Eo giáp & 6 & 5,9 \\
\hline & Hai thùy & 15 & 14,7 \\
\hline \multirow{3}{*}{ Phân loại TIRADS } & 3 & 6 & 5,9 \\
\hline & 4 & 68 & 66,6 \\
\hline & 5 & 28 & 27,5 \\
\hline \multirow{3}{*}{ Kết quả FNA } & Dương tính & 76 & 74,5 \\
\hline & Nghi ngờ & 23 & 22,5 \\
\hline & Âm tính & 3 & 2,9 \\
\hline
\end{tabular}

Trong nghiên cứu của chúng tôi, phần lớn các bệnh nhân có 1 u đơn độc (chiếm 75,5\%), chủ yếu phát hiện u ở giai đoạn sớm khi kích thước nhỏ hơn hoặc bằng $1 \mathrm{~cm}(73,6 \%)$. U ở cả 2 thùy gặp ở 15 bệnh nhân, chiếm 14,7\% các trường hợp. Đánh giá trên siêu âm theo phân loại TIRADS chủ yếu là TIRADS 4 (chiếm 66,6\%). Tất cả các bệnh nhân đều được chọc hút tế bào bằng kim nhỏ để chẩn đoán, trong đó đa số có kết quả ác tính, chiếm trên 74,5\%; 22,5\% bệnh nhân có kết quả nghi ngờ.

\section{Tình trạng di căn hạch}

\section{Bảng 2. Kết quả di căn hạch sau phẫu thuật}

Kết quả di căn hạch sau phẫu thuật

\begin{tabular}{llcc}
\hline \multirow{3}{*}{\begin{tabular}{l} 
Vị trí hạch di căn $(\mathrm{n}=61)$ \\
\cline { 2 - 4 }
\end{tabular}} & Nhóm trung tâm đơn thuần & 35 & 56,1 \\
\cline { 2 - 4 } & Nhóm hạch cổ bên đơn thuần & 3 & 10,5 \\
\cline { 2 - 4 } $\begin{array}{l}\text { Không phát hiện hạch trước } \\
\text { mổ }(\mathrm{n}=70)\end{array}$ & Khôm trung tâm + hạch cổ bên & 23 & 33,3 \\
\cline { 2 - 4 } & Có di căn hạch hạch & 37 & 52,9 \\
\hline
\end{tabular}

Tỉ lệ cắt toàn bộ tuyến giáp và cắt thùy + eo giáp lần lượt là $67,6 \%$ và $32,4 \%$. Đánh giá khối u trong mổ, có 21 trường hợp u phá vỡ vỏ và xâm lấn cơ trước giáp, 2 trường hợp u xâm lấn dây thần kinh thanh quản quặt ngược, 2 trường hợp xâm lấn thực quản và 2 trường hợp xâm lấn khí quản. Kết quả giải phẫu bệnh cho thấy chỉ có 2 trường hợp ung thư tuyến giáp thể nang, còn lại là ung thư tuyến giáp thể nhú, chiếm $98 \%$. Xếp loại giai đoạn u T1, T2, T3 và T4 có tỷ lệ lần lượt là $68,6 \%$, 
4,9\%, 20,6\% và 5,9\%. Tỉ lệ vét hạch cổ nhóm 6 và vét hạch cổ bên lần lượt là $85,3 \%$ và 30,4\%. Trong số những bệnh nhân có di căn hạch, phần lớn các trường hợp là di căn hạch nhóm trung tâm, đơn thuần hoặc đồng thời với nhóm hạch cổ bên. Chỉ có 3 trường hợp có hiện tượng di căn hạch nhảy cóc ở nhóm hạch cổ bên đơn thuần. Trong số 70 bệnh nhân không phát hiện hạch trước mổ, có $47,1 \%$ trường hợp phát hiện di căn hạch sau mổ.

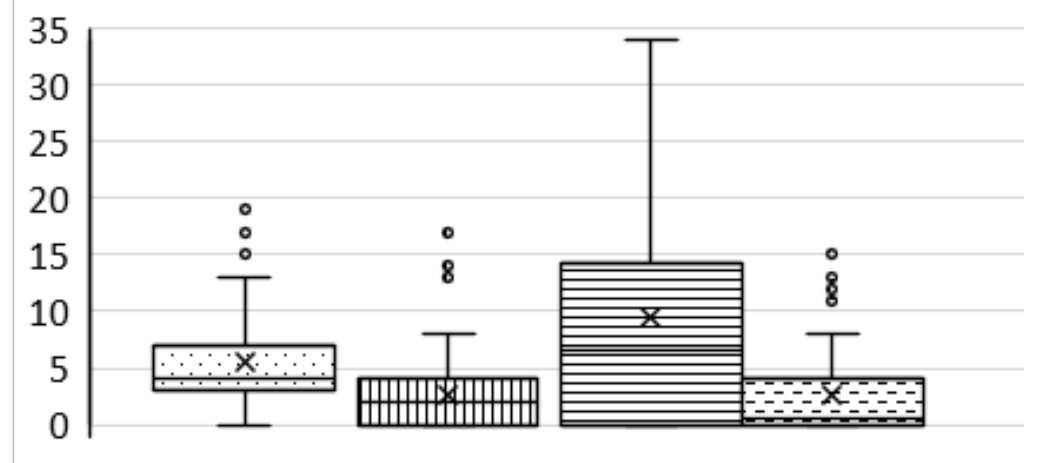

$\square$ Số lượng hạch nhóm 6 vét được

四 Số lượng hạch nhóm 6 di căn

目 Số lượng hạch cổ bên vét được

ㅁố lượng hạch cổ bên di căn

Biểu đồ 1. Số lượng hạch vét được và số lượng hạch di căn

(box plot biểu diễn trung vị và khoảng tứ phân vị, x: số lượng hạch trung bình)

Bảng 3. Các yếu tố liên quan đến tình trạng di căn hạch

\begin{tabular}{|c|c|c|c|c|}
\hline \multirow{2}{*}{\multicolumn{2}{|c|}{ Đặc điểm }} & \multicolumn{2}{|c|}{ Tình trạng di căn hạch n(\%) } & \multirow{2}{*}{ Giá trị p } \\
\hline & & Không di căn hạch & Có di căn hạch & \\
\hline \multirow{2}{*}{ Tuổi } & $<55$ & $31(37,3)$ & $52(62,7)$ & \multirow{2}{*}{0,22} \\
\hline & $\geq 55$ & $10(52,6)$ & $9(47,4)$ & \\
\hline \multirow{2}{*}{$\begin{array}{l}\text { Ung thư } \\
\text { hai thùy }\end{array}$} & Không & $38(44,8)$ & $48(55,2)$ & \multirow{2}{*}{0,022} \\
\hline & Có & $2(13,3)$ & $13(86,7)$ & \\
\hline \multirow{2}{*}{$\begin{array}{l}\text { Tình trạng } \\
\text { phá vỡ vỏ }\end{array}$} & Có & $6(22,2)$ & $21(77,8)$ & \multirow{2}{*}{0,026} \\
\hline & Không & $35(46,7)$ & $40(53,3)$ & \\
\hline \multirow{2}{*}{ Đa ổ } & Có & $7(28,0)$ & $18(72,0)$ & \multirow{2}{*}{0,152} \\
\hline & Không & $34(44,2)$ & $43(55,8)$ & \\
\hline \multirow{2}{*}{ Kích thước u } & $\leq 1 \mathrm{~cm}$ & $38(56,7)$ & $29(43,3)$ & \multirow{2}{*}{$<0,001$} \\
\hline & $>1 \mathrm{~cm}$ & $3(8,6)$ & $32(91,4)$ & \\
\hline
\end{tabular}




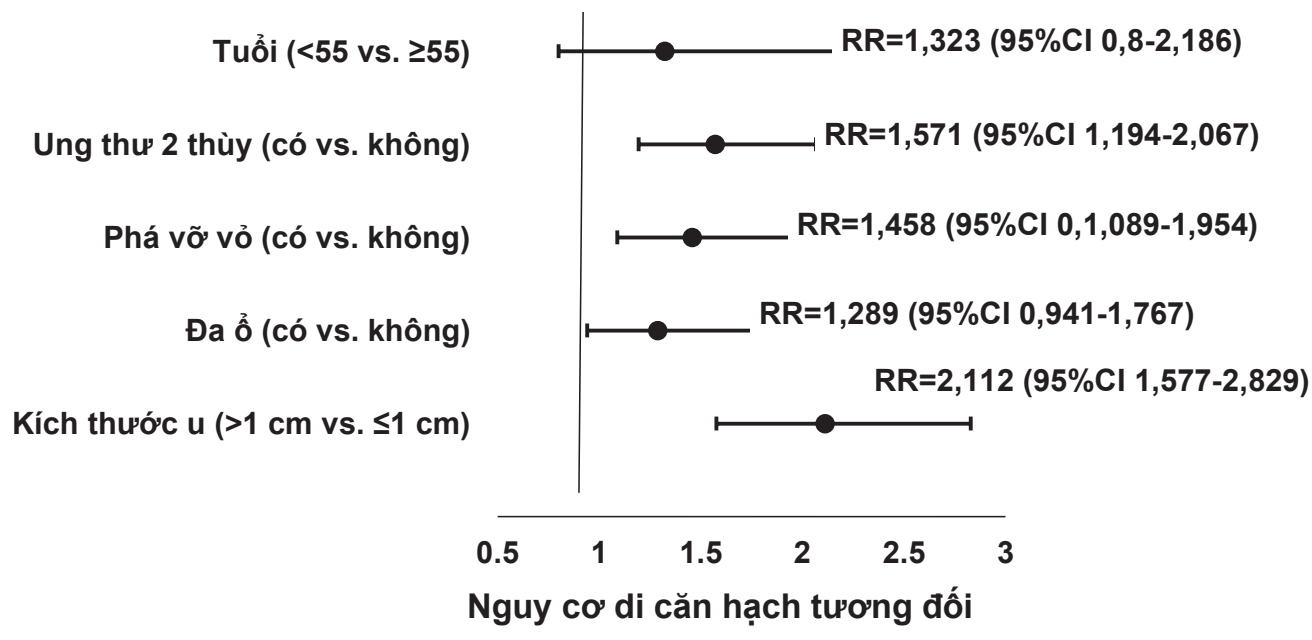

Biểu đồ 2. Nguy cơ di căn hạch tương đối (RR) theo một số yếu tố

Số lượng hạch nhóm 6 vét được trung bình là 5,43 $\pm 3,85$, trong đó có $2,61 \pm 3,26$ hạch di căn. Số lượng hạch cổ bên vét được trung bình là $9,38 \pm 10,95$, trong đó có $2,65 \pm 3,9$ hạch di căn. Tỉ lệ di căn hạch cao hơn ở các trường hợp tuổi < 55, ung thư hai thùy, u phá vỡ vỏ, tổn thương đa ổ và kích thước $u>1 \mathrm{~cm}$. Trong đó ung thư hai thùy, tình trạng phá vỡ vỏ và kích thước $u>1 \mathrm{~cm}$ có tỉ lệ di căn hạch cao hơn một cách có ý nghĩa thống kê $(p<0,05)$, với nguy cơ di căn hạch tương đối (RR) lần lượt là 1,571 (95\%Cl: 1,194-2,067), 1,458 (95\%Cl: 0,1,089-1,954) và 2,112 (95\%Cl: 1,5772,829) (Biểu đồ 2).

\section{BÀN LUẬN}

Trong nhóm bệnh nhân nghiên cứu của chúng tôi, độ tuổi trung bình là 40,9 \pm 13,0, bệnh nhân trẻ nhất là 11 tuổi, độ tuổi hay gặp nhất là 15 - 55 tuổi, chiếm tỉ lệ 81,4\%. Độ tuổi trung bình trong nhóm bệnh nhân của chúng tôi có thấp hơn so với một số nghiên cứu trước đây. Theo nghiên cứu của Hsieh và cộng sự (2012), độ tuổi trung bình tại thời điểm chẩn đoán của bệnh nhân ung thư tuyến giáp nam giới là $57,9 \pm 9,1 .{ }^{6}$ Trong nghiên cứu của Yan và cs trên 908 bệnh nhân nam giới ung thư tuyến giáp thể biệt hóa, độ tuổi trung bình là $44 \pm 12$ tuổi. ${ }^{7}$ Sự trẻ hóa về độ tuổi có thể do khám sàng lọc phát hiện sớm UTTG ngày càng phổ biến và sự quan tâm đến sức khỏe cộng đồng ngày càng được nâng cao. Ngoài ra, Liu và cộng sự cho thấy độ tuổi phát hiện ung thư tuyến giáp ở nam giới cao hơn nữ giới $(53,03$ $\pm 15,30$ so với $48,68 \pm 15,14, p<0,05),{ }^{8}$ có thể do phụ nữ thường quan tâm đến sức khỏe và thường đi khám định kì hơn. ${ }^{9}$

Trong nghiên cứu của chúng tôi, đa số các bệnh nhân đến khám ở giai đoạn sớm hoặc khám định kì tình cơ phát hiện u giáp khi u $\leq 1 \mathrm{~cm}$ (chiếm $65,7 \%$ ), u đơn ổ $(75,5 \%$ ) và khu trú ở 1 thùy giáp $(79,4 \%)$. Trên siêu âm, đánh giá u theo phân loại TIRADS chủ yếu là TIRADS 4 (66,6\%), không có TIRADS 1 và 2 . Kết quả xét nghiệm tế bào học cho thấy có $74,5 \%$ trường hợp ác tính, 22,5\% nghi ngờ và $2,9 \%$ bệnh nhân lành tính. Tuy vậy, các bệnh nhân có kết quả tế bào học lành tính đều có hình ảnh siêu âm nghi ngờ cao, TIRADS 4 nên chúng tôi quyết định phẫu thuật và sinh thiết tức thì trong mổ đều cho kết quả carcinoma tuyến giáp. Theo nghiên cứu của Nguyễn 
Tiến Lãng, tỉ lệ dương tính của chọc hút tế bào bằng kim nhỏ chiếm $86,7 \%$, âm tính giả 8,7\%. ${ }^{10}$ Theo Nguyễn Xuân Hậu (2017), tỷ lệ ác tính, nghi ngờ, lành tính lần lượt là $90,2 \%$, $5,6 \%, 4,2 \%$, độ nhạy 95,8\%. ${ }^{11}$ Các kết quả khẳng định giá trị cao của tế bào học trong chẩn đoán UTTG đồng thời cho thấy vai trò của sự phối hợp giữa lâm sàng, chẩn đoán hình ảnh, tế bào học và giải phẫu bệnh trong việc chẩn đoán và điều trị bệnh lý u tuyến giáp.

Trong nhóm bệnh nhân nghiên cứu, tỉ lệ vét hạch cổ nhóm 6 và vét hạch cổ bên lần lượt là $85,3 \%$ và $30,4 \%$. Có 61 bệnh nhân (chiếm $59,8 \%$ ) có di căn hạch, trong đó phần lớn các trường hợp là di căn hạch nhóm trung tâm, đơn thuần hoặc đồng thời với nhóm hạch cổ bên (chiếm lần lượt $56,1 \%$ và $33,3 \%$ ). Chỉ có 3 trường hợp có hiện tượng di căn hạch nhảy cóc ở nhóm hạch cổ bên đơn thuần. Tỷ lệ di căn hạch nhóm 6 trên quần thể bệnh nhân nam giới dao động từ 30\% - 60\% tùy nghiên

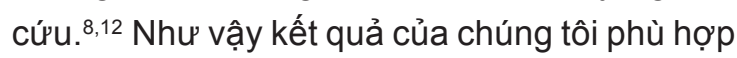
với các nghiên cứu trước đây đã báo cáo, cho thấy di căn hạch cổ là đặc điểm tương đối phổ biến trong ung thư tuyến giáp thể nhú. Xét về vị trí di căn hạch, thông thường, di căn hạch cổ nhóm bên thường xảy ra sau khi có di căn hạch nhóm trung tâm do đặc điểm của dòng dẫn lưu bạch huyết từ tuyến giáp, tuy nhiên, một số trường hợp có thể do ảnh hưởng của vị trí u (như u ở phần ba trên tuyến giáp) sẽ có hiện tượng di căn cách quãng (skip metastasis), đó là có di căn hạch cổ nhóm bên mà không có bằng chứng về di căn hạch nhóm trung tâm, tỉ lệ này thay đổi từ $2 \%$ đến $37,5 \%$ tùy từng nghiên cứu. ${ }^{13}$ Tỉ lệ di căn hạch tiềm ẩn ở các bệnh nhân không phát hiện hạch trước mổ trong nghiên cứu của chúng tôi là $47,1 \%$. Các nghiên cứu trước cũng cho thấy tỷ lệ di căn hạch tiềm ẩn là khá cao, đạt $45,1 \%$ theo Lê Văn Quảng (2018) và 49,3\% theo Nguyễn Thị
Thu Nhung (2019), điều này ủng hộ phẫu thuật vét hạch cổ dự phòng trong UTTG, đặc biệt là vét hạch cổ nhóm trung tâm dự phòng. . $^{14,15}$

Trong nghiên cứu của chúng tôi, tỉ lệ di căn hạch cao hơn có ý nghĩa thông kê ở nhóm bệnh nhân có kích thước $u>1 \mathrm{~cm}$, ung thư hai thùy, u phá vỡ vỏ xâm lấn ra ngoài tuyến với $p$ $<0,05$. Phân tích hồi quy cho thấy ung thư hai thùy $(\mathrm{RR}=1,571(95 \% \mathrm{Cl}: 1,194-2,067))$, tình trạng phá vỡ vỏ $(\mathrm{RR}=1,458(95 \% \mathrm{Cl}: 0,1,089$ - 1,954)) và kích thước $u>1 \mathrm{~cm}(\mathrm{RR}=2,112$ $(95 \% \mathrm{Cl}: 1,577$ - 2,829)) là các yếu tố có giá trị tiên lượng nguy cơ di căn hạch cổ. Liu và cộng sự (2017) tiến hành phân tích gộp 14 nghiên cứu bao gồm 4573 bệnh nhân ung thư tuyến giáp thể nhú cho thấy các yếu tố: giới tính nam, tuổi trẻ, kích thước u (> $5 \mathrm{~mm}$ đến $10 \mathrm{~mm}$ ), tổn thương đa ổ và ung thư hai thùy đã được ghi nhận như những yếu tố nguy cơ độc lập của di căn hạch cổ nhóm trung tâm. ${ }^{16}$ Phân tích gộp khác của Ning và cộng sự (2015) trên 8345 bệnh nhân cho thấy di căn hạch cổ nhóm trung tâm có liên quan chặt chẽ với các yếu tố: giới tính nam (RR = 1,36; 95\% Cl: 1,22-1,52, p= $0,001)$, tuổi trẻ (<45; RR =1,15;95\% Cl: 1,04 $-1,27, p=0,006)$, kích thước u lớn (>5 mm; $\mathrm{RR}=1,5195 \% \mathrm{Cl}: 1,32-1,65, \mathrm{p}=0,001)$, tổn thương đa ổ ( $\mathrm{R}=1,40 ; 95 \% \mathrm{Cl}: 1,27-1,54, \mathrm{p}$ $=0,001)$, và xâm lấn ngoài tuyến giáp ( $R R=$ 1,$81 ; 95 \%$ Cl 1,34-2,43, p=0,001) ${ }^{17}$. Như đã nói ở trên, tỷ lệ di căn hạch trong nghiên cứu của chúng tôi tương đồng so với các nghiên cứu trước đó trên quần thể bệnh nhân nam giới, và cao hơn so với nhóm bệnh nhân nữ giới. ${ }^{8,12}$ Có thể giải thích cho vấn đề này là do sự liên quan giữa nồng độ Estrogene và Progesterone khác nhau ở nam và nữ, tỷ lệ chuyển hóa nền ở nam giới cao hơn có thể là yếu tố thúc đẩy sự tăng sinh của tế bào ung thư, làm tăng tỷ lệ di căn hạch. 


\section{KẾT LUẬN}

Độ tuổi trung bình trong nghiên cứu là 40,9 13,0, lứa tuổi hay gặp nhất là 15 - 55 tuổi, chiếm tî lệ $81,4 \%$. Khối u chủ yếu ở 1 thùy $(79,4 \%)$, kích thước $\leq 1 \mathrm{~cm}(65,7 \%)$. Đánh giá trên siêu âm chủ yếu là TIRADS 4 (66,6\%), tỉ lệ chọc hút tế bào kim nhỏ chẩn đoán ác tính 74,5\%.

Đa số các bệnh nhân được phẫu thuật cắt toàn bộ tuyến giáp $(67,6 \%)$. Tỉ lệ di căn hạch chung là $59,8 \%$, tỉ lệ di căn hạch cổ nhóm 6 đơn thuần và kèm theo hạch cổ bên lần lượt là $56,1 \%$ và $33,3 \%$. Tỉ lệ di căn hạch tiềm ẩn là $47,1 \%$.

Các yếu tố: kích thước $u>1 \mathrm{~cm}$, ung thư hai thùy, u phá vỡ vỏ xâm lấn ra ngoài tuyến liên quan có ý nghĩa thống kê với tình trạng di căn hạch $(p<0,05)$.

\section{TÀI LIẸU THAM KHẢO}

1. Bray F, Ferlay J, Soerjomataram I, Siegel RL, Torre LA, Jemal A. Global cancer statistics 2018: GLOBOCAN estimates of incidence and mortality worldwide for 36 cancers in 185 countries. CA Cancer J Clin. 2018;68(6):394424. doi:10.3322/caac.21492.

2. Nguyễn Bá Đức (2009). Ung Thư Tuyến Giáp, Nhà Xuất Bản Y Học, 15 - 19.

3. Zeng Q, Chen GG, Vlantis AC, van Hasselt CA. Oestrogen mediates the growth of human thyroid carcinoma cells via an oestrogen receptor - ERK pathway. Cell Prolif. 2007;40(6):921935. doi:10.1111/j.1365-2184.2007.00471.x.

4. Ricarte-Filho J, Ganly I, Rivera M, et al. Papillary thyroid carcinomas with cervical lymph node metastases can be stratified into clinically relevant prognostic categories using oncogenic BRAF, the number of nodal metastases, and extra-nodal extension. Thyroid. 2012;22(6):575584. doi:10.1089/thy.2011.0431.

5. Micheli A, Ciampichini R, Oberaigner W, et al. The advantage of women in cancer survival: an analysis of EUROCARE-4 data. Eur J Cancer. 2009;45(6):1017-1027. doi:10.1016/j. ejca.2008.11.008.

6. Hsieh S-H, Chen S-T, Hsueh C, Chao T-C, Lin J-D. Gender-Specific Variation in the Prognosis of Papillary Thyroid Cancer TNM Stages II to IV. International Journal of Endocrinology. doi:10.1155/2012/379097.

7. Yan $\mathrm{H}-\mathrm{X}$, Pang $\mathrm{P}$, Wang $\mathrm{F}-\mathrm{L}$, et al. Dynamic profile of differentiated thyroid cancer in male and female patients with thyroidectomy during 2000-2013 in China: a retrospective study. Sci Rep. 2017;7(1):15832. doi:10.1038/ s41598-017-14963-z.

8. Liu C, Chen T, Zeng W, et al. Reevaluating the prognostic significance of male gender for papillary thyroid carcinoma and microcarcinoma: a SEER database analysis. Sci Rep. 2017;7. doi:10.1038/s41598-017-11788-8.

9. Bertakis KD. The influence of gender on the doctor-patient interaction. Patient Educ Couns. 2009;76(3):356-360. doi:10.1016/j. pec.2009.07.022.

10. Nguyễn Tiến Lãng. Đánh giá kết quả phẫu thuật cắt bỏ tuyến giáp phối hợp với 1131 điều trị ung thư tuyến giáp thể biệt hóa. Published online 2008.

11. Nguyễn Xuân Hậu. Đặc điểm lâm sàng, cận lâm sàng và tình trạng di căn hạch của ung thư tuyến giáp tại Bệnh viện Đại học Y Hà Nội. Tạp chí Y học. 2017;451(2):138-142.

12. Machens A, Hauptmann S, Dralle $H$. Disparities between male and female patients with thyroid cancers: sex difference or gender divide? Clin Endocrinol (Oxf). 2006;65(4):500505. doi:10.1111/j.1365 - 2265.2006.02623.x.

13. Nie X, Tan Z, Ge M. Skip metastasis in papillary thyroid carcinoma is difficult to predict in clinical practice. BMC Cancer. 2017;17. 
doi:10.1186/s12885-017-3698-2.

14. Quang LV, Hieu NV, Hau NX, Hung NV. Role of Sentinel Lymph Node Biopsy in Papillary Thyroid Carcinoma in Vietnam. uhod. 30(2):230-237.

15. Nguyễn Thị Thu Nhung. Đánh giá tình trạng di căn hạch tiềm ẩn trong ung thư biểu mô tuyến giáp giai đoạn sớm tại bệnh viện Đại học Y Hà Nội. Luận văn thạc sĩ y học. 2019. Trường Đại học Y Hà Nội.

16. Liu L-S, Liang J, Li J-H, et al. The incidence and risk factors for central lymph node metastasis in cNO papillary thyroid microcarcinoma: a meta-analysis. Eur Arch Otorhinolaryngol. 2017;274(3):1327-1338. doi:10.1007/s00405-016-4302-0.

17. Qu N, Zhang L, Ji Q-H, et al. Risk Factors for Central Compartment Lymph Node Metastasis in Papillary Thyroid Microcarcinoma: A Meta-Analysis. World J Surg. 2015;39(10):2459-2470. doi:10.1007/ s00268-015-3108-3.

\section{Summary}

\section{NODAL METASTASIS CHARACTERISTICS OF WELL- DIFFERENTIATED THYROID CANCER IN MALE PATIENTS}

This study aims to assess the nodal metastasis characteristics of differentiated thyroid cancer in male patients at Hanoi Medical University Hospital. We conducted a prospective cohort study of 102 male patients with well-differentiated thyroid carcinoma who were treated by surgery at Hanoi Medical University Hospital from July 2018 to August 2020. The mean age was $40.9 \pm 13.0$. Most patients $(79.4 \%)$ had unilateral tumor, with diameter $\leq 1 \mathrm{~cm}(65.7 \%)$. About two third $(66.6 \%)$ of the tumors were classified as TIRADS 4 according to ultrasound, and FNA indicated malignant result in $74.5 \%$ cases. Total thyroidectomy was performed on $67.6 \%$ patients. The overall rate of nodal metastasis was $59.8 \%$. Central neck compartment nodal metastasis was detected in $56.1 \%$ of the cases, while $33.3 \%$ patients had positive nodes in both central and lateral neck. The occult nodal metastasis rate was $47.1 \%$. Nodal metastasis was significantly associated with the following factors: tumor size $>1 \mathrm{~cm}$, bilateral tumor, and extrathyroidal extension $(p<0.05)$.

Keywords: differentiated thyroid cancer, male, lymph node metastasis. 